\title{
Üst Üriner Sistem Tümörlerinde Laparoskopik Radikal Nefroüreterektominin Günümüzdeki Tedavi Seçenekleri Arasındaki Yeri
}

\section{Current Status of Laparoscopic Radical Nephroureterectomy in the Treatment Modalities for Upper Urinary Tract Tumors}

\author{
Dr. Ahmet Güdeloğlu1, Dr. Cenk Yücel Bilen2 \\ ${ }^{1}$ Memorial Ankara Hastanesi, Üroloji Kliniği, Ankara, Türkiye \\ 2Hacettepe Üniversitesi Tıp Fakültesi, Üroloji Anabilim Dalı, Ankara, Türkiye
}

\section{Özet}

Üst üriner sistem tümörlerinin standart tedavisi halen böbreğin ve mesane kafı ile birlikte boylu boyunca üreterin çıkarıldığı açık radikal nefroüreterektomi (ARNÜ) ameliyatıdır. ARNÜ genellikle en az iki abdominal kesinin uygulandığı oldukça morbid bir ameliyattır. $\mathrm{Bu}$ ameliyatın minimal invaziv alternatifi olan laparoskopik radikal nefroüreterektomi (LRNÜ) onkolojik sonuçlar açısından etkinliği halen tartışmalı olan bir yöntemdir. Bu derlemede mevcut literatürün ışı̆̆ında LRNÜ ameliyatının teknik çeşitlilikleri, avantajları, dezavantajları ve onkolojik sonuçları diğer tedavi seçenekleri ile karşılaştırılarak ortaya konulmaya çalışılımıştır. (Üroonkoloji Bülteni 2014;13:122-125)

Anahtar Kelimeler: Üst üriner sistem tümörleri, açık radikal nefroüreterektomi, laparoskopik radikal nefroüreterektomi

\begin{abstract}
Summary
The standard treatment for upper urinary tract tumors is still open radical nephroureterectomy (ORNU), i.e. excision of the kidney with entire length of ureter and adjacent segment of bladder cuff. ORNU is a morbid procedure that usually requires at least two abdominal incisions. The minimally invasive alternative to this morbid operation is laparoscopic radical nephroureterectomy (LRNU), which is still controversial in terms of oncological outcomes. In this study we reviewed current literature in order to present technical varieties of LRNU procedure with advantages and disadvantages as well as oncological outcomes by comparing other treatment modalities. (Bulletin of Urooncology 2014;13:122-125)
\end{abstract}

KeyWords:Upperurinary tracttumors, open radical nephroureterectomy, laparoscopic radical nephroureterectomy

\section{Giriş}

Üst üriner sistem tümörleri (ÜÜST) çok yaygın görülmeyen tümörlerdir ve tüm ürotelyal tümörlerin kabaca \%5'ini oluşturmaktadır (1). Tümörün üst üriner sistemdeki lokalizasyonuna bakılmaksızın mesaneden kaf çıkarılması ile birlikte yapılan radikal nefroüreterektomi (RNÜ) ameliyatı bu hastalık için altın standarttır (2). Böbreğin tamamını, boylu boyunca üreteri ve üreterin devamındaki mesane kafını çıkarmak için açık teknikte bu ameliyat genellikle iki ayrı kesiden yapılır. Bu ameliyatın morbiditesini azaltmak için gösterilen çabalara laparoskopik cerrahideki gelişmeler öncülük etmiştir. Her ne kadar açık radikal nefroüreterektomi (ARNÜ) ameliyatı onkolojik sonuçlar üzerindeki etkinliğini kanıtlamış olsa da laparoskopik yaklaşım umut verici sonuçları ile birlikte açık tekniğe bir alternatif olarak yerini korumaktadır $(3,4)$. Bu derlemede biz laparoskopik radikal nefroüreterektomi (LRNÜ) ameliyatının günümüzdeki tedavi seçenekleri arasındaki yerini mevcut literatürün ışığında ortaya koymaya çalıştık.

Laparoskopik Radikal Nefroüreterektomide Teknik Çeşitlilik Illk LRNÜ ameliyatı 1991 yılında Clayman ve ark. tarafından tanımlanmıştır (5). Bu ameliyatı teknik olarak transperitoneal veya retroperitoneal yaklaşımlarla ve konvansiyonel veya el yardımlı yöntemlerle gerçekleştirilebilmek mümkündür. Ameliyat sonrası uzamış ileus transperitoneal yaklaşımın 
dezavantajı olarak düşünülebilir fakat radikal nefrektomi olgularının karşılaştıııldığı prospektif bir randomize çalışmada her iki yaklaşım arasında ameliyat sonrası ileus açısından fark olmadığı gösterilmiştir (6). Sadece renal hiler damarların kontrol süresi ve ameliyat süresi açısından retroperitoneal yaklaşım daha avantajlı olarak gösterilmiştir. Landman ve ark. konvansiyonel laparoskopik tekniği el yardımlı teknikle karşılaştırdıklarında kan kaybı, ağrı kesici ihtiyacı ve hastanede kalış süresinde fark gösterememişlerdir. Bununla birlikte konvansiyonel teknikte ameliyat süresi, el yardımlı teknikte ise iyileşme süreci daha uzun bulunmuştur (7). Bir başka karşılaştırmada konvansiyonel teknik, el yardımlı ve açık teknikle karşılaştırımış ve özellikle yüksek perioperatif riske sahip hastalarda daha az komplikasyon oranına sahip olduğu gösterilmiştir (8). Aynı çalışmada konvansiyonel tekniğin diğer iki tekniğe oranla \%21 oranında maliyet avantajına sahip olduğu da belirtilmiştir.

\section{Distal Üreterektomi ve Mesaneden Kaf Çıkarılması}

Böbreğin ve proksimal üreterin çıkarılmasından sonra kalan güdük kayda değer rekürrens riskine sahiptir. Ayrıca takipler esnasında güdüğün görüntülemesi ve endoskopik yaklaşımla takip edilmesi de güç olduğu için distal üreterin orifisinin ve çevreleyen mesane kafının üriner sisteme girilmeden bir bütün halinde çıkarılması RNÜ ameliyatının onkolojik prensiplerindendir. Distal üreterektomi ve mesaneden kaf çıkarılması için pek çok yöntem tanımlanmıştır. Açık eksizyon, transvezikal laparoskopik ayırma ve ligasyon tekniği, distal üreter ve mesane kafının laparoskopik olarak zımbalanması, üreter orifisinin transüretral rezeksiyonu (pluck tekniği) ve üreteral intussusepsiyon en yaygın kullanılan beş yöntemdir. Her birinin kendilerine göre avantajları ve dezavantajları olan bu yöntemlerden bazıları nefrektomiden önce uygulanırken bazıları da nefrektomiden sonra uygulanmaktadır.

En eski yöntem olmasına rağmen klasik açık teknikte distal üreter ve mesane kafı onkolojik prensiplerden ödün vermeden güvenli bir şekilde çıkarııır ve hala zamana karşı koymaktadır. Klingler ve ark. açık distal üreter eksizyonu ile birlikte LRNÜ uyguladıkları ve 22 ay takip ettikleri olgularını ARNÜ uyguladıkları benzer kohort gurubu ile karşılatırdıklarında tümör riski açısından artmış risk olmadığını göstermişlerdir (9). LRNÜ yaptıkları 19 hastanın birinde lokal nüks oluşmuşken ARNÜ yaptıkları 15 hastanın birinde lokal nüks gözlemlenmiştir. Açık ve laparoskopik RNÜ yaklaşımlarında hastalıksız sağ kalım açııından anlamlı farklılı̆̆ı olmadığı bir diğer çalışma da Matsui ve ark. tarafından yayınlanmışıı (10). On yedi LRNÜ'nün 17 ARNÜ ile karşılaştııılığı bu çalışmada hastalıksız sağkalım açısından fark gösterilememiştir $(p=0,68)$.

Transvezikal laparoskopik ayırma ve ligasyon tekniği mesanede tümörü olmayan hastalarda onkolojik geçerliliği kanıtlanmış bir yaklaşımdır. Fakat teknik zorluklarından ötürü kullanımı sınırlıdır. Gill ve ark. tanımladığı bu teknikte kabaca mesane içine 2 adet suprapubik trokar yerleştirilir (11). Sonrasında sistoskop yardımı ile hedef üreterin içine üreter kateteri ilerletilir. Sonrasında üreter Collin bıçağı ile üzerinde perivezikal yağ dokusu görülene kadar diseke edilir. Daha sonra üreter kateteri çıkarılarak Endoloop kilitlenir ve böylelikle tamamen ayrışmış olan üreterin ligasyonu sağlanmış olur. Gill ve ark. bu tekniği kullanarak yaptıkları 42 LRNÜ olgusunu 35 ARNÜ olgusu ile karşılaştırmışlardır ve her iki gurupta mesane rekürrensinde, lokal retroperitoneal ve port yeri rekürrensinde ve metastatik hastalık gelişiminde fark gösterilememiştir (12). Daha da ötesi her iki grupta kanser spesifik sağkalım (LRNÜ: \%97 vs. ARNÜ: \%87) ve genel sağ kalım da (LRNÜ: \%97 vs. ARNÜ: \%94) benzer olarak rapor edilmiştir. Bu teknik distal ve intramural üreterde tümörü olan hastalarda, mesanede aktif hastalık varlı̆ıında ve daha önceden pelvise radyoterapi alan hastalarda kontrendikedir.

Laparoskopik zımba tekniği kapalı üriner sistem prensibine başarılı bir şekilde uyarken geride üreter ve mesane kafı bırakma riskine sahiptir. Genellikle transperitoneal LRNÜ ameliyatında uygulanan bu yöntemde böbrek ayrılıp üreter aşağı yönde takip edilir. Süperior vezikal arter ile lateral pediküllerin kesilmesini takiben mesane de serbestlenir ve detrüsör kası ayrılarak üreter sefalad yönde çekilir. Son olarak mesane kafı ve distal üreter Endo-GIA zımba ile sağlam bir şekilde zımbalanır. Pelvik RT alan hastalar kötü iyileşme süreci beklenen hastalar daha az ekstravazasyon ve fistül riski nedeniyle bu teknikten fayda görebilirler. Potansiyel olarak zımba hattında geride bırakılabilecek canlı ürotelyal doku bu tekniğin bir dezavantajı olarak düşünülebilir (13). Tümör rekürrensi riskine ek olarak bu doku sistoskopik takipler esnasında görülemeyebilir ve zımbalanmış uç patolojik olarak net bir şekilde değerlendirilemez. Retroperitoneoskopik LRNÜ yapılan 23 hastanın yaklaşık 15 ay takip edildiği bir çalısmada mesane ve lokal rekürrens gösterilememiştir (14). Fakat Matin ve ark. laparoskopik zımba tekniğini transvezikal teknikle karşılaştırdıklarında daha sık pozitif cerrahi sınır olduğunu göstermişlerdir (15). Aynı zamanda genel sağkalım mesane kafı kontrol şekli ile korele olarak laparoskopik zımba yaklaşımında daha kötü bulunmuştur.

Üreter orifisinin transüretral rezeksiyonu (pluck tekniği) yöntemi ve üreteral intussusepsiyon tekniğinin her ikisinde de potansiyel olarak tümör ekilmesi riski mevcuttur. Pluck tekniğinde üreter orifisinin agresif rezeksiyonu perivezikal yağ dokusu görülene kadar devam ettirilir ve böylelikle laparoskopik ameliyat esnasında distal üreterin koparılması kolaylaştııııı. McNeill ve ark. bu yöntemi uyguladıkları LRNÜ olguları ile ARNÜ olgularını karşılaştırdıklarında benzer sonuçlar rapor etmişlerdir (16). Bununla birlikte pek çok çalışmada bu yöntemin uygulandığı olgularda tümör implantasyonunun riskinin arttığı da gösterilmiştir $(17,18)$. Bu teknik distal ve intramural üreterde, üreter orifisi etrafında tümörü olan olgularda, aktif mesane tümörü olan olgularda ve pelvik radyopterapi öyküsü olan hastalarda kontrendikedir.

Intussusepsiyon tekniğinde ise üreter laparoskopik işlem esnasında içinde üreter kateteri olduğu halde bağlanır Collin 
bıçağı ile etrafındaki mesane kafı insize edilerek traksiyonla üretradan çıkarıır. Clayman ve ark. bu yöntemi kullandıkları ve 5 yıllık takip ettikleri 14 ARNÜ olgusunda lokal tümör rekürrensi gösterememişlerdir (19). Bu teknik üreterde herhangi bir lokalizasyonda tümörü olan hastalarda kontrendikedir.

\section{Onkolojik Sonuçlar}

ÜÜST nedeniyle LRNÜ ameliyatı yapılan hastaların onkolojik sonuçlarının değerlendirilmesi mesane rekürrensi, lokal rekkürrens, uzak metastaz ve port yeri metastazları şeklinde sınıflandırılabilir.

LRNÜ ameliyatından sonra mesane rekürrensi oranı kabaca $\% 20$ ile \%40 arasında değişmektedir ve pek çok seride bu oranlar ARNÜ'deki oranlara eşit olarak rapor edilmiştir $(20,21,22,23,24)$. RNÜ sonrası mesane rekürrensi incelendiğinde bazı çalışmalar laparoskopik yaklaşımın mesane rekkürrensini arttırdığını iddia ederken bunun tam tersini destekleyen çalışmalar da mevcuttur $(25,26)$.

LRNÜ ameliyatı sonrası lokal rekkürrens hem açık hem de laparoskopik yaklaşım için sık karşılaşılan bir durum değildir. LRNÜ ameliyatı sonrası $\% 2,5$ ile $\% 10$ arasında değişen lokal rekürrens oranları da yine açık yaklaşıma eşit sayılabilecek düzeylerdedir $(27,28,29)$. Her ne kadar distal üretere yaklaşım şeklinin lokorejyonel rekürrensi etkilediği ve distal üreterin laparoskopik olarak çıkarıldığı olgularda açık olarak rezeke edilen olgularla karşılaştırıldığında daha yüksek lokorejyonel rekürrens oranı gözlemlendiği bildirilmişse de pek çok karşılaşıtırmada açık ve laparoskopik yaklaşım arasında fark gösterilememiştir $(20,23,30)$.

RNÜ ameliyatı yapılan hastaların önemli bir kısmı cerrahiden sonra progresyon gösterir. ÜÜST için prognostik faktörler; tümörün evresi, derecesi, cerrahi sınır, lenfovasküler invazyon, tümörün lokasyonu ve tüketilen sigara miktarı olarak sınıflandırılabilir (2). LRNÜ ameliyatı sonrası uzak metastaz görülme oranı \%10 ile \%28 arasında değişir ve bu oranlar ARNÜ ameliyatının metastaik hastalık geliştirme riski ile karşılaştırabilir oranlardır $(24,27,28,29)$. Yakın geçmişte açık ve laparoskopik yaklaşımın ortalama 13 yıllık takibinin karşılaştıııması yayınlandı ve 10 yıllık progresyonsuz sağkalım intimali açık ve laparoskopik yaklaşım için sırasıyla $\% 79$ ve $\% 76(p=0,7)$ bulunmuştur $(24)$. Bununla birlikte aynı çalışmada genel sağ kalım, kanser spesifik sağ kalım ve progresyonsuz sağ kalım açısından her iki gurup arasında anlamlı farkııık gösterilememiştir.

\section{Port Yeri Metastazları}

Port yeri metastazları laparoskopik üroonkoljik ameliyatlarda ciddi bir endişe kaynağıdır ve maalesef port yeri metastazı olarak rapor edilen olguların önemli bir kısmını (\%39) ÜÜST oluşturmaktadır (31). Bu nedenle LRNÜ halen büyük, invaziv ve multifokal tümörler (pT3, pT4 ve/veya $\mathrm{N}+/ \mathrm{M}+$ ) için standart tedavi opsiyonu olarak önerilememektedir (32). Port yeri metastazı ve tümör ekilmesi riskini azaltmak için pek çok önlem alınabilir; yeterli laparoskopik deneyim, asit varlığında laparoskopiden kaçınmak, gaz kaçağını önlemek için trokarları sabitlemekten ve gaz kaçağından kaçınmak, tümör sınııını minimal manüple etmek, morselasyondan kaçınmak, spesmen çıkarırken geçirgen olmayan torba kullanmak, dren konulacaksa abdomen havasını almadan önce koymak, laparoskopik aletlerin, trokarların, port yerlerinin ve büyük yaraların povidone-iodine ile temizlenmesi bu önlemlere örnek olarak verilebilir (33).

\section{Lenf Nodu Diseksiyonu}

Lenf nodu metastazı varlığının üst üriner sistem tümörlerinde hastalık rekürrensi ve kanser spesifik sağ kalımla direkt ilişkili olduğu gösterilmiş̧ir (34). Lenf nodu diseksiyonu (LND) RNÜ ameliyatında hastalığın doğru evrelenebilmesini ve ameliyat sonrası sonuçların öngörülebilmesini sağlar (35). Bu nedenle özellikle invaziv hastalık şüphesi varlığında (pT2-T4) RNÜ ameliyatı esnasında LND da yapılması önerilmektedir (2). Yakın zamanda önce Abe ve ark. LRNÜ ameliyatı esnasında LND işleminin etkin ve güvenli bir şekilde yapılabilirliğini göstermişlerdir (36). LRNÜ + LND uyguladıkları 39 hastanın 4 'ünde $(\% 10,3)$ lenf nodu metastazı tespit etmişlerdir. Bu çalışmada LND işlemi ortalama 30 dakika ile 1 saat arasında gerçekleştirilmiştir ve LND'ye bağlı ciddi bir komplikasyonla karşılaşıımamıştır. Doğru lenf nodu evrelemesi ameliyat sonrası tedavi stratejisini de etkileyerek sağ kalım avantajı sağlayabilir.

\section{Perioperatif Sonuçlar ve Komplikasyonlar}

LRNÜ tekniğinin tanımlandıktan sonraki erken dönem karşılaştırmalarında bile her ne kadar ameliyat süresi belirgin bir şekilde uzun olsa da ağrı kesici ihtiyacı ve hastanede kalış süresi açık tekniğe göre daha azdı ve iyileşme süreci hızıydı (37). LRNÜ tekniği halen, daha az ameliyat sonrası ağrı ve analjezik gereksinimi, daha az kan kaybı, daha hızlı iyileşme süreci, daha kısa hastanede kalış ve daha az maliyet gibi sonuçları nedeniyle bütün dünyada pek çok üroloji grubu tarafından ümit veren bir minimal invaziv opsiyon olarak kabul görmeye devam etmektedir (38). Yakın zamanda laparoskopik ve açık RNÜ ameliyat tekniklerini karşılaştıran çalışmalardan oluşan bir sistematik derleme göstermiştir ki; LRNÜ, ARNÜ'ye göre daha uzun ameliyat süresine sahip olmasına rağmen ( 241 dk vs. 203 dk), LRNÜ uygulanan hastalar hastanede daha kısa süre $(5,9$ gün vs. 8,7 gün) yatmaktadırlar (4). Bu çalışmaya göre kan kaybı da LRNÜ ameliyatlarında daha azdır ( $273 \mathrm{ml}$ vs. $476 \mathrm{ml}$ ). Her ne kadar intraoperatif komplikasyon riski de LRNÜ'de daha az $(\% 4,4$ vs. $\% 5,1)$ bulunduysa da bu farklılık istatistiksel olarak anlamlı değildir $(p=0,94)$. Bununla birlikte ameliyat sonrası hem minör (yara enfeksiyonu, geç post op kanama), hem de majör (ileus, insizyonel herni ve pnömotoraks) komplikasyonlar arasında da her iki gurup arasında fark gösterilememiştir (minör komplikasyonlar; LRNÜ: $\% 5,7$ vs. ARNÜ: $\% 7,8 p=0,40$, majör komplikasyonlar; LRNÜ: $\% 4,6$ vs. ARNÜ: $\% 3,8 p=0,61$ ).

\section{Sonuç}

Her ne kadar büyük hasta grupları ile yapılan prospektif randomize kontrollü çalışmalar olmasa da uzun takip süreli 
retrospektif çalışmalar göstermiştir ki ÜÜST için LRNÜ güvenli ve etkin bir minimal invaziv ameliyat yöntemidir. Robot yardımlı laparoskopik yaklaşımın erken dönem sonuçları bu tekniğin de güvenli bir şekilde uygulanabilirliğini gösterse de halen daha büyük hasta gruplarını içeren çalışmaların orta ve uzun dönem sonuçları merakla beklenmektedir (39). Bunula birlikte konvansiyonel laparoskopik teknik, rekürrenssiz sağ kalım, kanser spesifik sağ kalım ve genel sağ kalım açısından açık teknikle karşılaştırılabilir sonuçlara sahiptir. LRNÜ uygulanırken üriner sistemin bütünlüğünü bozmamaya özen gösterilmeli, tümörün aşırı manüplasyonundan kaçınılmalı ve distal üreter için doğru yöntemin seçildiğiden emin olunmalı. Bu onkolojik prensiplere saygı göstermede cerrahın deneyimi de asla yadsınamaz.

Mevcut literatüre göre lokalize ÜÜST'de deneyimli cerrahi merkez tarafından onkolojik prensiplerden ödün verilmeden yapılan LRNÜ ameliyatı en az ARNÜ kadar etkin ve daha minimal invaziv güvenli bir yöntemdir. Illerlemiş hastalıkta onkolojik sonuçlarının açık tekniğe olan benzerliği halen şüphelidir, bu konuda uzun takip süreli karşılaştırmalı çalışmalara intiyaç vardır.

\section{Önemli Noktalar}

1. ARNÜ ve LRNÜ arasında genel sağ kalım, kanser spesifik sağ kalım ve progresyonsuz sağ kalım açııından fark yoktur.

2. İnvaziv hastalık şüphesi varlığında laparoskopik LND uygulanmalıdır.

3. LRNÜ tekniği ARNÜ'ye göre daha az ameliyat sonrası ağrı ve analjezik gereksinimi, daha az kan kaybı, daha hızlı iyileşme süreci, daha kısa hastanede kalış ve daha az maliyete sahiptir.

4. Kan kaybı LRNÜ ameliyatlarında daha azdır.

5. Perioperatif ve postoperatif komplikasyonlar açısından ARNÜ ve LRNÜ arasında fark yoktur.

\section{Kaynaklar}

1. Siegel R, Naishadham D, Jemal A. Cancer statistics, 2013. CA Cancer J Clin 2013;63:11-30.

2. Rouprêt $M$, Babjuk $M$, Compérat $E$, et al. European guidelines on upper tract urothelial carcinomas: 2013 update. Eur Urol 2013;63:1059-1071.

3. Margulis V, Shariat SF, Matin SF, et al. Outcomes of radical nephroureterectomy: a series from the Upper Tract Urothelial Carcinoma Collaboration. Cancer 2009; 115:1224-1233.

4. Ni S, Tao W, Chen Q, et al. Laparoscopic versus open nephroureterectomy for the treatment of upper urinary tract urothelial carcinoma: a systematic review and cumulative analysis of comparative studies. Eur Urol 2012;61:1142-1153.

5. Clayman RV, Kavoussi LR, Figenshau RS, et al. Laparoscopic nephroureterectomy: initial clinical case report. J Laparoendosc Surg 1991;1:343-349.

6. Desai MM , Strzempkowski B, Matin SF, et al. Prospective randomized comparison of transperitoneal versus retroperitoneal laparoscopic radical nephrectomy. J Urol 2005;173:38-41.

7. Landman J, Lev RY, Bhayani S, et al. Comparison of hand assisted and standard laparoscopic radical nephroureterectomy for the management of localized transitional cell carcinoma. J Urol 2002; 167:2387-2391.

8. Baldwin DD, Dunbar JA, Parekh DJ, et al. Single-center comparison of purely laparoscopic, hand-assisted laparoscopic, and open radical nephrectomy in patients at high anesthetic risk. J Endourol 2003;17:161-167.

9. Klingler HC, Lodde M, Pycha A, et al. Modified laparoscopic nephroureterectomy for treatment of upper urinary tract transitional cell cancer is not associated with an increased risk of tumour recurrence. Eur Urol 2003;44:442-447.

10. Matsui $Y$, Ohara H, Ichioka K, et al. Retroperitoneoscopy-assisted total nephroureterectomy for upper urinary tract transitional cell carcinoma. Urology 2002;60:1010-1015.

11. Gill IS, Soble JJ, Miller SD, Sung GT. A novel technique for management of the en bloc bladder cuff and distal ureter during laparoscopic nephroureterectomy. J Urol 1999;161:430-434.

12. Gill IS, Sung GT, Hobart MG, et al. Laparoscopic radical nephroureterectomy for upper tract transitional cell carcinoma: the Cleveland Clinic experience. J Urol 2000;164:1513-1522.

13. Venkatesh R, Rehman J, Landman J, et al. Determination of cell viability after laparoscopic tissue stapling in a porcine model. I Endourol 2005; 19:744-747.

14. Yoshino $\mathrm{Y}$, Ono $\mathrm{Y}$, Hattori R, et al. Retroperitoneoscopic nephroureterectomy for transitional cell carcinoma of the renal pelvis and ureter: Nagoya experience. Urology 2003;61:533-538.

15. Matin SF, Gill IS. Recurrence and survival following laparoscopic radical nephroureterectomy with various forms of bladder cuff control. J Urol 2005; 173:395-400.

16. McNeill SA, Chrisofos M, Tolley DA. The long-term outcome after laparoscopic nephroureterectomy: a comparison with open nephroureterectomy. BJU Int 2000;86:619-623.

17. Arango O, Bielsa O, Carles J, Gelabert-Mas A. Massive tumor implantation in the endoscopic resected area in modified nephroureterectomy. J Urol 1997;157:1839.

18. Hetherington JW, Ewing R, Philp NH. Modified nephroureterectomy: a risk of tumour implantation. $\mathrm{Br}$ J Urol 1986;58:368-370.

19. Clayman RV, Garske GL, Lange PH. Total nephroureterectomy with ureteral intussusception and transurethral ureteral detachment and pull-through. Urology 1983;21:482-486.

20. Rassweiler JJ, Schulze M, Marrero R, et al. Laparoscopic nephroureterectomy for upper urinary tract transitional cell carcinoma: is it better than open surgery? Eur Urol 2004;46:690-697.

21. Simone G, Papalia R, Guaglianone S, et al. Laparoscopic versus open nephroureterectomy: perioperative and oncologic outcomes from a randomised prospective study. Eur Urol 2009;56:520-526.

22. Chung SD , Chen SC, Wang SM, et al. Long-term outcome of handassisted laparoscopic nephroureterectomy for pathologic T3 upper urinary tract urothelial carcinoma. J Endourol 2009;23:75-80.

23. Viprakasit DP, Macejko AM, Nadler RB. Laparoscopic nephroureterectomy and management of the distal ureter: a review of current techniques and outcomes. Adv Urol 2009:721371.

24. Stewart GD, Humphries KJ, Cutress ML, et al. Long-term comparative outcomes of open versus laparoscopic nephroureterectomy for upper urinary tract urothelial-cell carcinoma after a median followup of 13 years*. J Endourol 2011;25:1329-1335.

25. Xylinas E, Rink M, Cha EK, et al. Impact of distal ureter management on oncologic outcomes following radical nephroureterectomy for upper tract urothelial carcinoma. Eur Urol 2014;65:210-217.

26. Kuczyk MA, Sturm W, Stenzl A, Nagele U. Critical considerations regarding laparoscopic nephroureterectomy for the treatment of upper urinary tract carcinoma. European Urology Supplements 2007;6:555-559.

27. Bariol SV, Stewart GD, McNeill SA, Tolley DA. Oncological control following laparoscopic nephroureterectomy: 7-year outcome. J Urol 2004;172:1805-1808.

28. Rouprêt M, Hupertan V, Sanderson KM, et al. Oncologic control after open or laparoscopic nephroureterectomy for upper urinary tract transitional cell carcinoma: a single center experience. Urology 2007;69:656-661. 
29. Chung SD, Chueh SC, Lai MK, et al. Long-term outcome of handassisted laparoscopic radical nephroureterectomy for upper-tract urothelial carcinoma: comparison with open surgery. J Endourol 2007;21:595-599.

30. Muntener M, Schaeffer EM, Romero FR, et al. Incidence of local recurrence and port site metastasis after laparoscopic radical nephroureterectomy. Urology 2007;70:864-868.

31. Eng MK, Katz MH, Bernstein AJ, et al. Laparoscopic port-site metastasis in urologic surgery. J Endourol 2008;22:1581-1585.

32. Rouprêt M, Smyth G, Irani J, et al. Oncological risk of laparoscopic surgery in urothelial carcinomas. World J Urol 2009;27:81-88.

33. Tsivian A, Sidi AA. Port site metastases in urological laparoscopic surgery. J Urol 2003;169:1213-1218.

34. Cha EK, Shariat SF, Kormaksson M, et al. Predicting clinical outcomes after radical nephroureterectomy for upper tract urothelial carcinoma. Eur Urol 2012;61:818-825.
35. Yates DR, Hupertan V, Colin P, et al. Cancer-specific survival after radical nephroureterectomy for upper urinary tract urothelial carcinoma: proposal and multi-institutional validation of a postoperative nomogram. Br J Cancer 2012;106:1083-1088.

36. Abe T, Harabayashi T, Shinohara N, et al. Outcome of regional lymph node dissection in conjunction with laparoscopic nephroureterectomy for urothelial carcinoma of the upper urinary tract. J Endourol 2011;25:803-807.

37. McDougall EM , Clayman RV, Elashry O. Laparoscopic nephroureterectomy for upper tract transitional cell cancer: the Washington University experience. J Urol 1995;154:975-979.

38. Meraney AM, Gill IS. Financial analysis of open versus laparoscopic radical nephrectomy and nephroureterectomy. J Urol 2002; 167:1757-1762.

39. Lim SK, Shin TY, Rha KH. Current status of robot assisted laparoscopic radical nephroureterectomy for management of upper tract urothelial carcinoma. Curr Urol Rep 2013;14:138-146. 